\title{
Adam Drozdek
}

University of Economics, Kraków

adam_drozdek@poczta.onet.pl

ORCID: 0000-0002-0942-3347

\section{Ruling as a form of settlement of an individual tax case: Considerations exemplified by tax overpayment}

\begin{abstract}
The ruling on the application of tax overpayment is a formal act which does not prejudge the existence of tax arrears, but which provides information on the way the payment is credited. The credit is legally binding. Therefore, the ruling on the credit only confirms that it has been effected. The amount of the tax liability or arrears shall not be verified in the credit decision. The amounts shall be fixed or determined in accordance with their respective procedures. The ruling is a formal condition for the overpaid tax to be credited against outstanding and current tax liabilities. The ruling has legal effects in the sense that as for the date of crediting the overpayment, tax arrears no longer exist.
\end{abstract}

KEYWORDS

ruling, tax proceedings, tax overpayment

\section{Introduction}

In the legal regulations of the pre-war Tax Ordinance, ${ }^{1}$ the ruling - i.e. tax ruling - was adopted as a procedural form of action of the tax authority. The rulings were the second form of action of tax authorities in tax proceedings. In this way, due to the procedural consequences, the legislator separated the rulings from the decisions, which were sovereign acts of tax authorities issued in the course of assessment and appeal proceedings. On this basis thereof, the tax authority imposed, reduced or repealed the tax or fine. At present, it is considered that the ruling as an individual act of tax law issued on the basis of the current Tax Ordinance ${ }^{2}$ differs from the decision in terms of the subject of ruling and, consequently, the scope of its legal effects.

1 Cf. Articles 38 and 39 of the Act of 15 March 1934 Tax Ordinance, consolidated text, Dz.U. (Journal of Laws) of 1936, no. 14 , item 134 .

2 Act of 29 August 1997 Tax Ordinance, consolidated text, Dz.U. (Journal of Laws) of 2020, item 1325, as amended, hereinafter referred to as the "Tax Ordinance". 
While undertaking the analysis of issues defined by the subject of this study, it is crucial to first of all pay attention to the decisions issued by tax authorities in the form of the ruling to credit the tax overpayment against future and current tax liabilities in terms of the tax and legal relationship. Undertaking research in this area is all the more important, since the concept of a legal act gave rise to many controversies in the doctrine of tax law and the judicature, which refers to the issuance of the ruling by the tax authority, thus creating a new legal state (a constitutive administrative act), or, on the contrary, not creating a new legal state - an administrative declaratory act. At the same time, the issue is part of a problem analysed by the representatives of the doctrine of tax law, which may also support the process of interpreting the provisions of Chapter 9 of the Tax Ordinance entitled Overpayment.

\section{The essence of the tax overpayment}

The legal regulations of the current Tax Ordinance pursuant to Article $72 \S 1$ refer to the essence of tax overpayment. In compliance with the aforementioned provision, the amount of tax overpaid or unduly paid shall be deemed to be the tax overpayment. In the first case, the tax debtor's benefit is higher than it should result from current law - it is the overpaid benefit. On the other hand, in the second case, the tax overpayment happens when the tax benefit should not be allowed in light of the applicable law - it is the undue benefit. Furthermore, the tax overpayment refers to the facts outlined in $\$ 1$ points (2) to (4) of Article 72 of the Tax Ordinance, where other cases are listed, which, in the legislator's opinion, should also be considered as the overpayment of tax. ${ }^{3}$ Having regard to the content of the aforementioned provision, the tax overpayment should also be considered the amount of tax unduly collected by the remitter or in the amount greater than the amount due, as well as refer to a situation where the benefit of the remitter or collector resulting from the decision on the tax liability of such entities was determined unduly or in the amount greater than the amount due, and then, after the decision has been annulled or declared invalid, the tax authority issued another correct assessment decision of a lower value, the overpayment shall constitutes the difference between the tax and the tax resulting from the latter decision. The tax overpayment is also the amount unduly paid by third parties within the meaning of Article 107 of the Tax Ordinance and by heirs, i.e. cash benefits paid on the basis of a tax liability decision or a decision determining the amount of the testator's tax liability, under which the benefit due was overstated or the undue benefit was determined or established.

It is also worth noting that the legislator treats other cash amounts on the same level as the tax overpayment, which shall include, for example, paid arrears, interest for late payment of outstanding tax advances and extension fee amount. ${ }^{4}$ In this way, the tax overpayment shall be deemed to mean not only the advances towards personal and corporate

3 Cf. A. Szymczak, Nadpłata podatku powstała w wyniku orzeczenia trybunału konstytucyjnego, "Ruch Prawniczy, Ekonomiczny i Socjologiczny" 2013, Vol. 4, p. 108.

4 Cf. Article $72 \S 2$ of the Tax Ordinance. 
income tax, tax instalments with interest or extension fee amount, but also other non-tax cash benefits, which include budgetary fees and non-tax receivables. ${ }^{5}$

Additionally, the tax overpayment refers to payments of the distributed profit of the State Treasury sole proprietorships and state enterprises, ${ }^{6}$ the amount of tax on the basis of a legal provision, which was later declared unconstitutional by the Constitutional Tribunal, or the amount of tax for which the legal basis was the provision being subject to examination by the Court of Justice of the European Union, and - pursuant to the ruling issued by the CJEU - it follows that this provision is incompatible with European Union law.

On the basis of the above-cited legal regulations, it may be interpreted that the concept of the tax overpayment consists of two types of benefits of a different legal nature. On one hand, it is a pecuniary benefit which has arisen as a result of the cash payment higher than that resulting from a tax obligation or liability. On the basis of the characteristics of this benefit, it is evident that the benefit is related to the existing legal relationship between the tax creditor and the taxpayer. The tax overpayment understood in such manner is an overpayment in the strict sense. The second type of benefits are those unduly paid. In such case, there is no legal obligation or tax liability. There is no link resulting from the tax and legal relationship between the tax authority and the person paying the benefit. Undue benefit also exists where there was a legal basis for its payment at the time the benefit was provided, but after the payment was made, the legal basis disappeared, for example, due to the fact that the decision has been annulled or declared invalid. The presented type of the tax overpayment is the tax overpayment in the largo sense. Such a conclusion is all the more justified given that the tax overpayment constitutes the benefit paid to the public-law association (State Treasury, local government units) with the intention of fulfilling the tax obligation of the taxpayer. The benefit results from the transfer of assets by the body regulating tax benefits to benefit of the tax authority. The payer is mistakenly convinced that there is a tax obligation or liability that did not exist at all or existed, but the basis therefor disappeared. The essence of the tax overpayment is the payment of the benefit to the tax authority, which is overpaid or unduly paid at that particular moment. ${ }^{8}$

\section{Ruling as a form of action by the tax authority taken with respect to the tax overpayment}

Without going into detail on the definition of a tax provision, as it would go beyond the thematic framework of this study, it should be considered that the tax provision is adopted on the basis of the provisions of the Tax Ordinance and, exceptionally, in accordance with the generally applicable rules of substantive tax law, an externally formalised legal act of

5 Judgment of the Supreme Administrative Court of 24 February 2006, II FSK 402/05, Lex no. 297971; judgment of the Voivodeship Administrative Court in Wrocław of 13 April 2016, I SA/Wr 1742/15, Lex no. 2084573.

6 Cf. Article $73 \$ 2$ point 3 of the Tax Ordinance.

7 Cf. Article 74 of the Tax Ordinance.

8 A. Drozdek, Stosunki podatkowo-prawne w nadpłacie podatków, Toruń 2020, p. 176. 
the tax authority of a judicial nature that is essential to adjudicate in an individual situation, with the characteristics of sovereignty and unilateralism expressed in the admissibility of forced execution. It means that the ruling should be classified as a type of a specific legal act, based on the procedural and substantive legal norms, as a form of action of the tax authority, with characteristics similar to those of a decision. An important difference between the tax ruling and the tax decision, as a procedural form of action of the tax authority, is the subject matter of the ruling, the procedural form and the character of legal effects that they produce. ${ }^{9}$

The essential legal role of the tax ruling is contained in Article 216 of the Tax Ordinance, Chapter 7, Section 4 entitled "The ruling". The ruling contains two paragraphs, based on which the scope of its application and the content of the decision should be established. Pursuant to $\$ 1$ of the above-mentioned legal regulation, the tax authority issues decisions in the course of the proceedings. In turn, $\$ 2$ explicitly states that the subject matter of the rulings are the issues related to pending tax proceedings inconclusive as to the substance of the case unless the provisions of the Tax Ordinance provide otherwise. The content of the aforesaid legal regulation clearly indicates that there are three forms of individual administrative acts issued by the tax authority in the form of the decision, namely:

- the acts issued in the course of tax proceedings,

- the acts concerning the issues arising in the course of the proceedings, and

- cases inconclusive as to the substance. ${ }^{10}$

All of the above-mentioned forms of the ruling, as a formalised sign of the tax authority's activities within the framework of the tax and legal relationship, shape the rights and obligations of the tax debtor and creditor. As a declaration of will by the tax creditor under the tax-legal standard, it is characterised by strictly defined features, which undoubtedly include the following:

- made as a result of the application of substantive and procedural law,

- made in relation to the established facts,

- made in the manner and form as provided for in procedural law,

- to be made public by publishing it on the website in order to have legal effect. ${ }^{11}$

An example of the ruling concerning issues related to tax proceedings conducted by the tax authority is the situation where the tax overpayment is charged against outstanding and current tax liabilities. In compliance with Article 76a of the Tax Ordinance, in cases where the overpayment is credited against overdue and current tax liabilities, the tax authority shall issue a decision against which the taxpayer may bring an appeal. If in the event when the overpayment is credited against tax arrears, the payment made does not cover the amount of the tax arrears plus default interest, the tax authority shall credit the payment

9 J. Borkowski, B. Adamiak, Postanowienia, in: Ordynacja podatkowa. Komentarz, B. Adamiak, J. Borkowski, P. Borszowski, R. Mastalski, J. Zubrzycki (eds.), Warszawa 2017, p. 1273.

10 Cf. R. Hauser, Z. Niewiadomski, A. Wróbel (eds.), System prawa administracyjnego, Vol. 9, Prawo procesowe administracyjne, Warszawa 2010.

11 B. Adamiak, Z problematyki właściwości sądów administracyjnych (Article $3 \$ 2$ point 4 of the Law of the Administrative Courts Procedure), “Zeszyty Naukowe Sądownictwa Administracyjnego" 2006, no. 2, p. 7. 
pro rata against the amount of the tax arrears and the amount of default interest in the proportion in which the amount of the tax arrears remains on the date of payment to the amount of default interest. Moreover, the aforementioned legal regulation provides that if the taxpayer is subject to tax obligations under various titles, the payment made shall be credited towards the tax in accordance with the taxpayer's indication, and in the absence of such indication - towards the tax obligation with the earliest date of all the taxpayer's tax obligations. Where the taxpayer has tax liabilities whose term of payment has expired, the payment made shall be credited towards the tax arrears with the earliest date of payment of the tax specified by the taxpayer, and in the absence of such indication or absence of tax arrears in the tax indicated towards the tax arrears with the earliest date of payment out of all the taxpayer's tax arrears. The second paragraph of the aforementioned legal regulation indicates a closed catalogue of situations in which the overpayment is credited to tax arrears by the tax authority. ${ }^{12}$ Thus, in the first case, the overpayment of tax arises on the date of payment by the taxpayer of undue tax or in an amount greater than due, collection of undue tax by the remitter or in an amount greater than due, payment made by the remitter or collector of the receivables resulting from the decision on their tax liability, if such receivables were unduly determined or in an amount greater than due, and payment made by a third party or heir of the receivables resulting from the decision on tax liability or the decision determining the amount of tax liability of the testator, if such receivables were unduly determined or in an amount greater than due. In the latter case, on the other hand, the creation of the overpayment was dependent on the taxpayer's actions, which include the submission of the application to ascertain the tax overpayment.

In the decisions issued by the tax authorities in cases related to the application of the tax overpayment to overdue and current tax liabilities, the legislator has not specified whether they create a new legal status or, on the contrary, do not create a new legal status, but only confirm the existing status. ${ }^{13}$ The question of the legal nature of the ruling on the application of the tax overpayment to outstanding and current tax liabilities has raised and continues to raise numerous doubts not only in the legal doctrine, but also in the judicature system.

12 Article $76 \mathrm{a} \$ 2$ of the Tax Ordinance.

13 The constitutive and declaratory provisions differ in content and legal effect they produce. Therefore, it should be pointed out that a constitutive provision is an administrative act of that kind based on which a specific tax and legal relationship is created, changed or terminated. It shapes, creates new rights and duties of the recipient whom they concern. The moment from which it produces legal effects may be defined in different ways - the moment when it is issued, becomes final or the judgment is served. On the other hand, a declaratory provision is a type of an administrative act which does not create, abolish or change the existing tax and legal relationship, but confirms the existing rights and obligations of its addressee (taxpayer) as well as the limits of the legal sphere of a given entity established by law. It shall establish, in a legally binding manner, the existence of a specific legal or factual situation which exists by operation of law, irrespective of the fact that the judgment has been given. In other words, the legal effects occur by the very operation of law, but the issue of such an act is a necessity, as it is only from the moment of its issuance that a party may exercise the rights and obligations resulting from a legal situation whose existence has been established by a declaratory act. The declaratory acts have "retroactive" legal effects - ex tunc. Cf. J. Lang, J. Służewski, M. Wierzbowski, A. Wiktorowska, Polskie prawo administracyjne, Warszawa 1992, p. 196; A. Gomułowicz, Powstawanie zobowiązań podatkowych, part 1, "Monitor Podatkowy" 1998, no. 6, p. 169; J. Szermański, Akt administracyjny, in: Encyklopedia prawa, E. Smoktunowicz, C. Kosikowski (eds.), Białystok-Warszawa 2000, p. 35. 
The legal nature of the ruling on the application of the overpayment to overdue and current tax liabilities is perceived in many different ways in the administrative and judicial decisions. In many of their decisions, the adjudication panels employ the thesis that the deduction of the overpayment for tax arrears is by virtue of law and the decision issued in this case is of declaratory nature. One of the examples could be the judgment of the Voivodeship Administrative Court in Gliwice of 25 September 2019, case file no. I SA/Gl $528 / 19,{ }^{14}$ in which it is stated that the amount of the refund of the tax difference (on goods and services) is set off against tax arrears by operation of law and takes place on the date of submission of the return disclosing the tax refund in question. On the other hand, the tax authority is legally obliged to issue a decision, which only states the resulting (existing) ex lege credit towards tax arrears. The ruling for the knowledge of the tax authority and the taxpayer is intended to create the possibility of verification and then its further use in future tax settlements with the tax authority. Therefore, it confirms and articulates, in the form of an administrative act in an individual case, that a certain amount of the tax difference to be refunded has been credited to the subject tax arrears on the date prescribed by law and in compliance with the ruling, but undoubtedly does not constitute the above legal status. The application of the refund of the tax difference to specific tax arrears results, also by virtue of law, in the expiry of the tax liability out of which the tax arrears settled in this way are derived. In its judgment of 14 March 2008, the Voivodeship Administrative Court in Wrocław indicated that both in the case of crediting the payment made by the taxpayer to overdue liabilities as well as crediting the overpayment to overdue tax liabilities, the tax authority is obliged to issue a decision in which it shall determine the credited amount and towards which tax liabilities. ${ }^{15}$ If the provisions of tax law provide for such a procedure - and the tax liability expires due to the crediting of the overpayment or payment - it should be concluded that the effect in the form of expiration of the liability by crediting the overpayment or payment against outstanding tax liabilities takes place on the date of delivery of the decision on crediting the overpayment or payment against outstanding tax liabilities to a party. Another thesis was put forward by the Supreme Administrative Court in its ruling of 23 March 2020, in which it stated that the tax overpayment is credited to tax arrears by operation of law on the maturity date of the tax arrears if the overpayment was made earlier than the tax arrears. ${ }^{16}$ The issuance of the ruling on the tax overpayment is not a prerequisite for the occurrence of such overpayment, as it has already existed when the taxpayer paid the undue tax. Therefore, not only the date of the decision on determination of the overpayment, but also the date of submission of the motion for its determination is irrelevant for defining the moment when the overpayment shall be credited against the tax arrears. ${ }^{17}$ However, such interpretation must lead to the conclusion that the application of the overpayment towards tax against arrears is a material and technical activity and the ruling referred to in Article $76 a \$ 1$ of the Tax Ordinance is a formal condition for crediting

14 Judgment of the Voivodeship Administrative Court in Gliwice of 25 September 2019, I SA/Gl 528/19, Lex no. 2734353.

15 Judgment of the Voivodeship Administrative Court in Wrocław of 14 March 2008, I SA/Wr 1210/07, Lex no. 469269.

16 Judgment of the Supreme Administrative Court of 23 March 2020, I FSK 186/20,Lex no. 2854733.

17 D. Malinowski, Glosa do wyroku WSA z dnia 26 marca 2004 r., III SA 1385/03, "Przegląd Podatkowy” 2005, no. 1, p. 45. 
the overpayment against tax arrears and current tax liabilities. This, in turn, implies the conclusion that, when crediting the tax overpayment towards tax arrears, the tax authority is not entitled to verify the correctness of tax returns submitted by the taxpayer or decisions determining the amount of tax liabilities. ${ }^{18}$

However, the Supreme Administrative Court expressed a completely different view in its judgment of 23 June 2005, ${ }^{19}$ stating that the nature of the ruling on the application of the tax overpayment towards future and current tax liabilities takes effect retroactively, which means that the ruling is constitutive. The thesis on the retroactive effects of the ruling to credit the overpayment against tax arrears was also put forward by the Voivodeship Administrative Court in Kraków in its judgment of 3 February 2009. The court pointed out that the application of tax overpayment towards arrears is a material and technical activity and the ruling referred to in Art. 76(a) $\$ 1$ of the Tax Ordinance is a formal condition for crediting the overpayment towards overdue and current tax liabilities. To effectively apply the tax overpayment, it is important that the tax arrears towards which the overpayment is to be applied exist (not time-barred) on the date of the crediting. ${ }^{20}$ It means that the date of the ruling is not decisive if the overpayment is credited to future and current liabilities. The ruling has legal effects in the sense that as for the date of crediting the overpayment, the tax arrears cease to exist. On the other hand, in accordance with the thesis of the ruling of the Voivodeship Administrative Court in Wrocław of 8 January 2008, the need to issue a decision on the application of the overpayment towards current and overdue tax liabilities results from the constitutional principle of the rule of law expressed in Article 7 of the Constitution. In compliance with the aforesaid principle, on the basis of the ruling on the tax overpayment to be credited, the authority shall perform material and technical activities in the form of entries in the taxpayer's settlement accounts, and not vice versa. This is also supported by the importance of the legal effects of crediting the tax overpayment in the form of expiry of the tax liability. In the ruling, the tax authority shall indicate the arrears towards which the overpayment is credited, thus, only in respect of such arrears may the effects of crediting be accepted. Therefore, the ruling shows that the tax authority decides on the tax overpayment under tax law. ${ }^{21}$ A much more far-reaching thesis was formulated by the Supreme Administrative Court in its ruling of 27 March 2019. ${ }^{22}$ When commenting on administrative acts, the Court stated that the administrative acts that are constitutive in tax proceedings may be effective ex nunc or extunc. The temporal effectiveness of the administrative constitutive acts depends on the hypothesis or the disposition of a specific material standard or content of a rule of jurisdiction related thereto. The substantive rules ultimately determine whether, and to what extent, the administrative acts based thereon have retroactive effect (extunc), hence - from a certain point in time, preceding the date

18 Cf. Judgment of the Voivodeship Administrative Court in Gliwice of 20 June 2018, I SA/Gl 1363/17, Lex no. 2534288

19 Judgment of the Supreme Administrative Court of 23 June 2005, FSK 2475/04, LEX no. 173255.

20 Judgment of the Voivodeship Administrative Court in Kraków of 3 February 2009, I SA/Kr 1585/08, Lex no. 504663.

21 Judgment of the Voivodeship Administrative Court in Wrocław of 8 January 2008, I SA/Wr 1561/07, Lex no. 504663.

22 Judgment of the Supreme Administrative Court of 27 March 2019, I OSK 1540/17, LEX no. 2665611. 
of notification (announcement) of the administrative act, at which a given element or all statutory circumstances took places.

Attempts have also been made in the doctrine of tax law to determine the legal nature of the ruling regarding the application of the tax overpayment towards overdue and current tax liabilities. In the opinion of J. Zubrzycki, in view of Article 75 of the Tax Ordinance, it should be pointed out that the application of the tax overpayment against tax arrears is a material and technical act, and the decision issued by the tax authority is only a formal condition for the application of the tax overpayment against future and current tax liabilities. $^{23}$ A contrario, it seems justified to say that the date of the ruling by the tax authority is therefore not the date on which the tax overpayment shall be credited towards the tax arrears. It means that the tax overpayment is credited on the date when the overpayment occurs, i.e. by operation of law. A similar view is also presented by L. Etel, who is of the opinion that the tax overpayment should be credited, as a matter of principle, on the date of the overpayment - in the cases referred to in Article $73 \$ 1$ points $1-3$ and 5 and $\$ 2$ of the Tax Ordinance - or on the date of submission of the motion to establish tax overpayment. Therefore, the rule is that the overpayment is credited on the date on which the overpayment occurs. However, in the case of the motion to establish tax overpayment, the crediting should be effected on the date of submission of such motion. ${ }^{24}$ Therefore, the above justifies the conclusion that the ruling issued by the tax authority to credit the tax overpayment against future and current tax liabilities has retroactive effects meaning that the tax arrears cease to exist as for the date of crediting the overpayment.

An important view on this issue is presented by J. Gorąca-Paczulska, who draws attention to the fact that the tax overpayment is subject to ex officio crediting. In practice, it means that a taxpayer does not have to apply for the ruling on the crediting of the tax overpayment towards current and overdue liabilities, as it is the tax authority that is obliged to issue the said ruling under the legal standard. It is also confirmed by the literal wording of Article 76(a) $\$ 2$ of the Tax Ordinance, where the legislator precisely indicates that the crediting of the tax overpayment "shall take place as of the date", by operation of law, without interference from the tax authority. A contrario, the legislator assumes that the tax overpayment "is not credited on the day". Furthermore, it should be stressed that no provision of the Tax Ordinance prejudges the declarative or constitutive nature of the ruling on the crediting of the tax overpayment towards current and outstanding liabilities. Where a taxpayer has accumulated more tax arrears, the tax overpayment shall be credited towards the arrears with the earliest payment date. In exceptional cases, the taxpayer may indicate which tax arrears are to be credited by the authority. In such a manner, the will of the taxpayer is binding on the tax authority. In principle, the tax authority thus reflects events that have already taken place in the past. In the opinion of the author, the legislator allowed, as an exception, to include in the ruling a constitutive element, expressed as a possibility of considering the taxpayer's will to credit the overpayment towards tax arrears other than the arrears with the

23 J. Zubrzycki, Zobowiązanie podatkowe, in: Ordynacja podatkowa. Komentarz, B. Adamiak, J. Borkowski, P. Borszowski, R. Mastalski, J. Zubrzycki (eds.), Wrocław 2017, p. 511.

24 Cf. L. Etel, Komentarz do art. 76(a) Ordynacji podatkowej, Lex./El. 2020. 
earliest payment date. In such case, the tax authority, by issuing the ruling on the crediting of the tax overpayment towards overdue and current tax liabilities, declaratively states that on the date of creation or submission of the motion to establish tax overpayment, ${ }^{25}$ the tax overpayment was credited towards the tax arrears in the amount of the difference between the tax obligation and the tax liability on account of the overdue. In such case, the constitutive element of the ruling shall oblige the taxpayer to indicate the arrears towards which the overpayment has been legally credited. The tax authority, on the basis of such element of the ruling, shall amend the legal situation of the taxpayer arising after the overpayment has been credited in this regard by operation of law (constitutive element). ${ }^{26}$ On the other hand, M. Slifirczyk mentions that the ruling to credit the tax overpayment towards future and current liabilities is issued for the knowledge of the tax authority and the taxpayer to create an opportunity to verify and then use it in future tax settlements. Therefore, the ruling confirms and articulates, in the form of an administrative act in an individual case, that a certain amount of the tax difference to be refunded has been credited to the subject tax arrears on the date prescribed by law and in compliance with the ruling, but certainly does not constitute the above legal status. ${ }^{27}$ The adoption of this view means that the application of the tax overpayment against future and current liabilities initiates a specific procedure, which ends with a material and technical transaction by the tax authority in the form of crediting the overpayment against future tax liabilities. It is worth mentioning at this point that the provisions of tax law do not allow tax authorities to freely handle the motion, and the very fact that the motion has been submitted already produces certain legal effects of a substantive legal nature. ${ }^{28}$ It means that the submission of the motion to credit the tax overpayment towards future and current tax liabilities has retroactive effects, and therefore leads to the expiry of the tax liability as soon as the tax overpayment is incurred. The aforesaid fact is confirmed by the doctrine of tax law. In the opinion of M. Popławski, the provisions are thus formal in nature, i.e. they only confirm the accounting activities of the tax authority. ${ }^{29}$ The tax overpayment shall be credited towards tax arrears or current tax liabilities by virtue of law as of the date on which the tax overpayment arose and not as of the date of issuing the ruling in this respect by the entity obliged under the tax and legal relationship of the tax overpayment. ${ }^{30}$

Bearing in mind the views of the academic circles and the judiciary, it should be stated that the ruling to credit the tax overpayment against outstanding and current tax liabilities constitutes a formal administrative act, which does not prejudge the existence of the tax

25 Article $76 \mathrm{a} \$ 2$ of the Tax Ordinance.

26 J. Gorąca-Paczulska, Nadpłata, in: Ordynacja podatkowa. Komentarz, H. Dzwonkowski (ed.), Warszawa 2019 , p. 597.

27 M. Ślifirczyk, Zaliczenie nadpłaty i zwrotu podatku jako przedmiot rozstrzygnięć organów podatkowych, in: Ordynacja podatkowa w praktyce. Rozstrzygnięcia organów podatkowych i skarbowych, R. Dowgier (ed.), Białystok 2014, pp. 269283.

28 M. Ślifirczyk, Charakter prawny wniosku o zaliczenie nadpłaty na poczet przyszłych zobowiązań podatkowych, in: R. Dowgier (ed.), Ordynacja podatkowa. Kontrola realizacji zobowiązań podatkowych, Białystok 2012, pp. 440-449.

29 M. Popławski, Uprawnienia podatkowe. Procedura dochodzenia należności podatkowych od Skarbu Państwa lub jednostek samorządu terytorialnego, Warszawa 2014, p. 236.

30 A. Drozdek, op. cit., p. 332. 
arrears, but provides information on how to credit that payment. The tax overpayment shall be credited by virtue of law when the tax and legal relationship of the tax overpayment arises. Therefore, the ruling on the application of the tax overpayment only confirms that the overpayment has been applied, since in the ruling to credit the overpayment, the tax authority does not verify the amount of the tax liability or tax arrears. The ruling on the application of the tax overpayment is not constitutive in nature. It only defines what has been done and illustrates the method of crediting for the taxpayer, thus, enables the taxpayer to check its accuracy. Therefore, the ruling indicates the liability towards which the tax authority has applied the overpayment, the amount towards which the tax authority has applied the principal and the amount towards which the tax authority has applied the interest as well as the date on which the tax authority has credited a given amount, why that date is considered the crediting date, the period and rules for pro rata calculation and settlement of the interest.

\section{Final conclusions}

In conclusion, it should be stated that the ruling on the application of the tax overpayment towards current and outstanding liabilities as an administrative declaratory act of the tax authority is a formal confirmation of the activities of its accountants. In the case of the tax overpayment that occurs by virtue of law, the tax overpayment shall be credited against existing tax arrears.

The tax overpayment as a subjective right is always a correlate of the tax authority's obligation, i.e. its competence in the strict sense of the word. The existence of subjective law determines the behaviour of the tax authority from the beginning to the end. The authority may not depart from such pattern of behaviour. The crediting of the tax overpayment under the tax and legal relationship does not depend on whether the entity (tax authority) becomes obliged due to the tax overpayment or the disposition of tax overpayment is issued by the entitled entity (taxpayer, payer, collector). The entitled entity is allowed to dispose of the amount of the tax overpayment only with regard to future tax liabilities. If the entitled entity submits a relevant request in this respect, the entity obliged due to the tax overpayment shall be bound thereby, which means that the entity shall implement the disposition of the entitled entity. In such case, the right of the entitled entity shall not be limited either by the order or the deadline for payment of future tax liabilities. Therefore, it must be assumed that, as a result of the request submitted by the entity entitled due to the tax overpayment, the entity shall be exempt from the obligation to pay the tax covered by the overpayment. Furthermore, it should be noted that in the event when the entity entitled due to the tax overpayment does not indicate the titles towards which it wants to credit the amount of the tax overpayment, the entity obliged due to the tax overpayment should collect a relevant statement from such entitled entity. The introduction of such a solution results in the fact that the entity obliged due to the tax overpayment may not decide on its own towards which tax liabilities the overpayment should be credited. 
Once the tax overpayment occurs, the taxpayer, payer or collector, by becoming a creditor of the tax authority, does not have full freedom to dispose of the overpaid benefit. To protect the interests of the State Treasury, the legislator introduces certain rules concerning the return of the overpayment, which may not be modified by the parties to the relationship. It follows unequivocally from the public and law method of the regulation. However, what is positive is the mutual offsetting of tax claims, which, under Article 76 $\$ 3$ of the Tax Ordinance, shall be available to both parties to the tax and legal relationship of the tax overpayment. The analysis of the issues related to the crediting of the tax overpayment towards overdue and current tax liabilities has shown that the overpayment should be credited on the date on which the overpayment occurs, i.e. in situations referred to in Art. $73 \$ 1$ points $1-3$ and 5 and $\$ 2$ of the Tax Ordinance. However, in the case of the motion to establish tax overpayment, the overpayment should be credited on the date of submission of the motion, i.e. in this case, the day on which the tax and legal relationship of the tax overpayment arises.

\section{Literature}

Adamiak B., Z problematyki właściwości sądów administracyjnych (art. $3 \$ 2$ pkt 4 p.p.s.a.), "Zeszyty Naukowe Sądownictwa Administracyjnego" 2006, no. 2.

Borkowski J., Adamiak B., Postanowienia, in: Ordynacja podatkowa. Komentarz, B. Adamiak, J. Borkowski, P. Borszowski, R. Mastalski, J. Zubrzycki (eds.), Wrocław 2017.

Drozdek A., Stosunki podatkowo-prawne w nadpłacie podatków, Torun 2020.

Etel L., Komentarz do art. 76(a) Ordynacji podatkowej, Lex./El. 2020.

Gomułowicz A., Powstawanie zobowiązań podatkowych, part I, "Monitor Podatkowy” 1998, no. 6.

Gorąca-Paczulska J., Nadpłata, in: Ordynacja podatkowa. Komentarz, H. Dzwonkowski (ed.), Warszawa 2019.

Hauser R., Niewiadomski Z., Wróbel A. (eds.), System prawa administracyjnego, Vol. 9, Prawo procesowe administracyjne, Warszawa 2010.

Lang J., Służewski J., Wierzbowski M., Wiktorowska A., Polskie prawo administracyjne, Warszawa 1992.

Malinowski D., Glosa do wyroku WSA z dnia 26 marca 2004 r., III SA 1385/03, "Przegląd Podatkowy" 2005, no. 1 .

Popławski M., Uprawnienia podatkowe. Procedura dochodzenia należności podatkowych od Skarbu Państwa lub jednostek samorządu terytorialnego, Warszawa 2014.

Szermański J., Akt administracyjny, in: Wielka encyklopedia prawa, E. Smoktunowicz, C. Kosikowski (eds.), Białystok-Warszawa 2000.

Szymczak A., Nadpłata podatku powstała w wyniku orzeczenia trybunału konstytucyjnego, "Ruch Prawniczy, Ekonomiczny i Socjologiczny" 2013, Vol. 4.

Ślifirczyk M., Charakter prawny wniosku o zaliczenie nadpłaty na poczet przyszłych zobowiąań podatkowych, in: Ordynacja podatkowa. Kontrola realizacji zobowiązań podatkowych, R. Dowgier (ed.), Białystok 2012. 
Ślifirczyk M., Zaliczenie nadpłaty i zwrotu podatku jako przedmiot rozstrzygnięć organów podatkowych, in: Ordynacja podatkowa w praktyce. Rozstrzygnięcia organów podatkowych i skarbowych, R. Dowgier (ed.), Białystok 2014.

\section{Legislative acts}

Act of 15 March 1934 Tax Ordinance, consolidated text, Dz.U. (Journal of Laws) of 1936, no. 14, item 134.

Act of 29 August 1997 Tax Ordinance, consolidated text, Dz.U. (Journal of Laws) of 2020, item 1325, as amended.

\section{Judicial decisions}

Judgment of the Supreme Administrative Court of 23 June 2005, FSK 2475/04, LEX no. 173255. Judgment of the Supreme Administrative Court of 24 February 2006, II FSK 402/05, LEX no. 297971. Judgment of the Supreme Administrative Court of 27 March 2019, I OSK 1540/17, LEX no. 2665611. Judgment of the Supreme Administrative Court of 23 March 2020, I FSK 186/20, LEX no. 2854733. Judgment of the Voivodeship Administrative Court in Wrocław of 8 January 2008, II SA/Wr 1561/07, Lex no. 492006.

Judgment of the Voivodeship Administrative Court in Wrocław of 14 March 2008, II SA/Wr 1210/07, Lex no. 469269.

Judgment of the Voivodeship Administrative Court in Kraków of 3 February 2009, II SA/Kr 1585/08, Lex no. 504663.

Judgment of the Voivodeship Administrative Court in Wrocław of 13 April 2016, II SA/Wr 1742/15, Lex no. 2084573.

Judgment of the Voivodeship Administrative Court in Gliwice of 20 June 2018, II SA/Gl 1363/17, Lex no. 2534288.

Judgment of the Voivodeship Administrative Court in Gliwice of 25 September 2019, II SA/Gl 528/19, Lex no. 2734353. 